\title{
SHARIA FINTECH AS AN INSTRUMENT OF NATIONAL ECONOMIC RECOVERY AMID THE COVID-19 PANDEMIC
}

Nurul Istifadhoh ${ }^{1}$, Inarotul A'yun ${ }^{2}$, Hafidhotul Mufidhoh ${ }^{3}$

STEI Kanjeng Sepuh Gresik ${ }^{1}$, STAI Nahdlatul Ulama Tuban², STEI Kanjeng Sepuh Gresik ${ }^{3}$ isti@steikassi.ac.id, inna.ra202@gmail.com, hafidhotulmufidah@gmail.com

\begin{abstract}
The focus of this research is to uncover the existence of sharia fintech which is considered able to accelerate the process of accelerating economic recovery due to pandemics that have an impact on the slowdown of the national scale economy.

This research was conducted using an in-depth literature study with qualitative descriptive analysis techniques approach. The data collection method used is the library method. The literature used as a reference is scientific articles, mass media articles, textbooks, and other online literature searches that correspond to this research.

The results of the study show fintech contributes positively to the national economic recovery and the increase in state revenues during the pandemic. This can be improved by supporting strengthening government regulations for inclusive and sustainable fintech growth so that fintech has the potential to be a triggering factor for the digital financial services industry in Indonesia.
\end{abstract}

Keywords: Sharia Fintech, National Economy, Covid-19 Pandemic

\section{Pendahuluan}

Ditengah pandemi covid-19, tekanan terjadi pada perekonomian Indonesia yang mengarah pada resesi ekonomi dengan menimbulkan efek domino yang dimulai dari sector kesehatan, beralih ke masalah sosial dan terakhir pada sector ekonomi serta para pelaku usaha. Badan Pusat Statistik (BPS) telah mencatatkan laju pertumbuhan ekonomi pada Kuartal pertama (Januari-Maret) 2020 hanya tumbuh dikisaran 2,9 persen. Angka ini mengalami perlambatan dari 4,97\% pada Kuartal empat tahun 2019. Bahkan tidak hanya itu, pertumbuhan ekonomi tercatat jauh dibawah pencapaian Kuartal pertama tahun 2019 yang mencapai atau berada dikisaran 5,07 persen. Kemudian pada Kuartal kedua Tahun 2020 laju pertumbuhan ekonomi Indonesia menjadi minus 5,32 persen. Angka itu berbanding terbalik pada Kuartal kedua Tahun 2019 sebesar 5,05\%. (Wuryandani, 2020).

Kendati kondisi perekonomian Indonesia yang sedang mengalami perlambatan, menjadikan tranformasi digital menjadi sebuah keharusan terutama pada inklusi keuangan. Ditambah saat ini kita telah masuk pada era perkembangan ekonomi digital yang mulai massif, sehingga masyarakat dituntut untuk terus mengembangkan berbagai inovasi penyediaan layanan di berbagai bidang, di antaranya dalam kegiatan layangan keuangan berbasis tehnologi. Fintech sebagai satu inovasi penyedia layanan jasa keuangan berbasis teknologi informasi menjadi salah satu jawaban untuk dapat memulihkan kembali ekonomi nasional di tengah masa pandemi. Melalui strategi nasional dalam rangka pemulihan ekonomi akibat 


\section{Vol 8, No 2: Agustus 2021. 66-77 \\ ISSN: 2460-9889 (Cetak) \\ ISSN: 2580-3565 (Online)}

https://journal.trunojoyo.ac.id/dinar/index

adanya tekanan oleh pandemi covid-19, maka dipandang perlu adanya kolaborasi antar lembaga pemerintahan dan para pemangku kepentingan yang ada secara baik dan juga terstruktur (Marginingsih, 2021).

Saat ini kita sudah masuk pada era digital yang nampaknya telah membawa dampak yang signifikan pada perubahan gaya hidup manusia yang ada pada saat ini, gaya hidup dimana manusia lebih memaksimalkan menggunakan akses telepon pintar atau yang lebih dikenal dengan sebutan smartphone. Penggunaan smartphone di kalangan masyarakat ternyata memiliki pengaruh yang cukup besar pada tingkat pertumbuhan di sektor ekonomi. Dan salah satu yang menjadi pegangan dalam menopang sektor ekonomi yaitu adanya lembaga keuangan, kemudian saat ini ditambah dengan keberadaan financial technology atau yang disingkat dengan fintech yang dapat mempermudah perusahaan untuk mengatur manajemen dan persaingan pasar global, serta membuat perusahaan lebih dekat dengan user, termasuk dalam bisnis keuangan. Salah satu contoh dari penggunaan fintech sebagai instrumen penguat yaitu tampak pada sektor friendly moslem tourism, yang mana penggunaan fintech sebagai bisnis keuangan dapat mendorong lembaga keuangan menjadi lebih berkembang dan progresif (Alwi, 2018).

Oleh sebab itu, fintech berpotensi mengambil peran dalam membantu proses pemulihan ekonomi nasional akibat perlambatan ekonomi yang disebabkan oleh pandemi dengan pergerakannya yang masih dinilai positif sampai saat ini. Peran Fintech dalam meningkatkan inklusi keuangan terlihat dalam beberapa karakter dasar fintech yang dapat disimpulkan sebagai berikut: pertama, peningkatan akses serta desentralisasi sistem keuangan, dimana kemajuan teknologi yang dipergunakan memungkinkan inklusi keuangan baik dari komunitas individu ataupun UMKM yang tidak bankable untuk dapat kiranya tetap berperan sebagai media penyedia dan pengguna dana dalam sistem keuangan; kedua, peningkatan transparansi, akuntabilitas serta kolaborasi lintas sektor, dimana teknologi juga dapat menjadi penyedia transparansi, penelusuran, pertanggungjawaban, dan pembagian informasi yang lebih besar kepada pemerintah, masyarakat dan swasta untuk saling bekerja sama; dan ketiga, biaya yang lebih rendah melalui peningkatan efisiensi, kecepatan dan otomatisasi sebab karakter fintech bisa memberikan akses layanan keungan formal berbasis digital pada seluruh lapisan msyarakat (Hasan, Hassan, \& Aliyu, 2020).

Perkembangan fintech saat ini mengalami peningkatan dan berkembang dengan pesat, hal ini terlihat dari nilai transaksi industri fintech di Indonesia pada tahun 2017 yang diperkirakan mencapai US \$18,65 miliar. Bahkan menurutErns \& Young memproyeksikan, bahwa berbagai layanan produk dari fintech sendiri dapat menarik 150 juta pelanggan pada tahun 2021. Hadirnya fintech juga berkontribusi terhadap perkembangan UMKM. Tidak hanya membantu pembiayaan modal ventura, akan tetapi adanya layanan digital pembayaran dan manajemen keuangan meski memiliki aspek negatif, yaitu adanya transfer risiko untuk biaya dendanya atau sistem bunga tetap. Selanjutnya berdasarkan survei nasional data Otoritas Jasa Keuangan (OJK) Indonesia (2016) mennyebutkan bahwa tingkat literasi keuangan syariah hanya 8 persen atau lebih rendah dari keuangan konvensional 


\section{Vol 8, No 2: Agustus 2021. 66-77 \\ ISSN: 2460-9889 (Cetak) \\ ISSN: 2580-3565 (Online)}

https://journal.trunojoyo.ac.id/dinar/index

sebesar 30\%. Selain itu, untuk penyertaan keuangan Islam baru sebesar 11\%, lebih rendah dari inklusi keuangan konvensional sebesar 68\%, hal ini berkaitan dengan kondisi dimana Indonesia yang berada diposisi ke-9 di pasar keuangan Islam diberbagai dunia. Ini menunjukkan bahwa tingkat literasi keuangan di Indonesia yang masih terbilang rendah dan inklusi dalam keuangan Islam tampaknya menjadi sebuah paradoks, mengingat Indonesia merupakan negara dengan populasi Muslim terbesar di dunia dan dianggap sebagai negara paling siap menjadi pusat Fintech Islam di dunia. (Yarli, 2018)

Menurut Otoritas Jasa Keuangan (OJK), dari 124 perusahaan Fintech yang terdaftar dan memiliki izin sebagai firma pinjaman peer-to-peer (P2P) 11 diantaranya adalah fintech syariah. Mereka adalah PT Ammana Fintek Syariah (Ammana), PT Dana Syariah Indonesia (Dana Syariah), dan PT Investree Radhika Jaya (Investree), PT. Dhuha Madani Syariah, PT. Berkah Fintech Syariah, dikarenakan fintech sendiri masih tergolong baru, maka studi tentang fintech syariah yang dilakukan akhir-akhir ini masih sangat sedikit. Oleh sebab itu, perlu adanya perbaikan regulasi dimasa yang akan datang sehingga saling menguntungkan pihak terkait dengan terus mengembangkan teknologi keuangan agar unsur-unsur yang bertentangan dengan Islam seperti (riba, gharar, maysir, tadlis, risywah, israf, dan transaksi terlarang lainnya) dapat dihilangkan, maka dibutuhkan studi yang mendalam tentang aspek yurisprudensi Islam. Sehubungan dengan tantangan ini, ada beberapa strategi yang dianjurkan, yaitu: a) adanya peraturan oleh otoritas untuk mewujudkan manfaat (mashlahah) dalam transaksi menggunakan Fintech, b) meningkatkan kapasitas Sumber Daya Manusia, serta c) meningkatkan upaya kolaboratif dalam kegiatan bisnis. (Hasan et al., 2020)

Terlihat dari data statistik oleh OJK per-juli 2020, dimana akumulasi dari penyaluran pembaiayaan pinjaman tahun 2020 (januari-juli) melalui financial technology (finteh) sebesar 35 triliun dengan capaian pertumbuhan sebesar 135\% (Juli, 2020, YoY). Minat masyarakat dalam mengajukan pinjaman melalui fintech syariah menunjukkan adanya pertumbuhan positif meskipun ditengah pandemi. Relevansi akan keberadaan fintech syariah saat ini sebagai sebuah sarana layanan keuangan digital semakin terlihat, khusunya bagi sebagian kelompok masyarakat yang sampai saat ini belum terjamah oleh lembaga keuangan formal. Fintech berperan dalam pemerataan ekonomi terutama pada sektor UMKM dimana sebaran dari pinjamannya meningkat ke wilayah-wilayah diluar jawa yang naik sebesar 107 persen (year-on-year) (INDEF, 2020).

Sektor financial technology merupakan strategi penting dalam memperluas penyebaran inklusi keuangan juga dalam peningkatan kesejahteraan masyarakat. Hal ini juga didorong oleh semakin masifnya para pengguna smartphone yang mana menguntungkan hadirnya fintech ditengah-tengah masyarakat hingga ke daerah pedesaan, menjadi salah satu sarana penghubung dan solusi bagi masyarakat yang selama ini kesulitan jangkauan oleh lembaga keuangan formal. Dengan penggunaan smartphone, masyarakat bisa menggunakan layanan keuangan berbasis tekhnologi dengan mudah dalam memenuhi kebutuhan serta menjaga keberlanjutan bisnisnya dalam upaya pemulihan ekonomi nasional yang mengalami dampak akibat perlambatan ekonomi oleh pandemi covid-19. (Novi, 2019). 


\section{Tinjauan Pustaka}

\section{Financial Technology (Fintech)}

Secara umum, financial technology dapat diartikan sebagai sebuah inovasi teknologi dalam layanan transaksi keuangan. Menurut peraturan Bank Indonesia Nomor 19/12/PBI/2017 tentang penyelenggaraan teknologi finansial, teknologi finansial didefiniskan sebagai suatu penggunaan teknologi dalam sistem keuangan yang menghasilkan produk, layanan, teknologi, dan/atau model bisnis baru serta dapat berdampak pada stabilitas moneter, stabilitas sistem keuangan, dan/atau efisiensi, kelancaran, keamanan, dan keandalan sistem pembayaran. Lebih lanjut menurut peraturan Bank Indonesia Nomor 19/12/PBI/2017 tentang penyelenggaraan teknologi finansial, tujuan dilaksanakan teknologi finansial adalah untuk mendorong suatu inovasi di bidang keuangan yaitu dengan menerapkan perlindungan konsumen dan manajemen resiko, serta kehati-hatian untuk tetap menjaga stabilitas sistem keuangan, stabilitas moneter, serta sistem pembayaran yang aman, efisien, andal, dan lancar (Miskam, Yaacob, \& Rosman, 2019).

Entitas bisnis wajib mengeikuti ruang lingkup dalam teknologi finansial, yaitu mulai dari pendaftaran, kemudian regulatory sanbox dan perijinan serta persetujuan, hingga yang terakhir adalah pemantauan dan pengawasan. Tekonologi keuangan yang berasal dari sector perekonomian merupakan sector yang menjadi kunci peningkatan ekonomi yang terus berkembang sesuai dengan kebutuhan masyarakat. Teknologi keuangan sudah tidak asing lagi digunakan secara umum dan luas oleh msyarakat di negara maju, akan tetapi saat ini teknologi keuangan sudah mulai muncul, mulai digunakan, dan terus tumbuh di negaranegara berkembang, salah satunya di Indonesia. Fintech atau financial technologi saat ini tengan menjadi harapan baru untuk bisa memberikan berbagai kemudahan dalam melakukan transaksi keuangan secara digital dalam berbagai sector (Trimulato, 2019).

\section{Fintech Syariah}

Berbagai negara berkembang mulai mengadopsi konsep financial technology, baik secara penuh ataupun sebagian, seperti di Tanzania. Terdapat penelitian yang dilakukan olehSulayman di Tanzania. Menurut Sulayman (2015) Tanzania merupakan negara yang mengalamiperubahan pertumbuhan yang bisa dikatakan secara mendadak dalam bidang industri keuanganislam selama beberapa waktu terakhir. Namun sayangnya, kemajuan dalam bidang industrikeuangan islam tidak diimbangi dengan kemajuan dalam hal fasilitas teknologi yang dapatmenampung perubahan tersebut. Bila kelemahan itu terus dibiarkan, maka akan membuatsemakin buruknya keadaan sosial ekonomi masyarakat. Lebih lanjut Sulayman menambahkan,untuk mengimbangi peningkatan industri keuangan islam dan agar dapat bertahan, maka perludilakukan beberapa langkah, yaitu: mempromosikan literasi keuangan Islami, mengambiltindakan pada waktunya, mempertahankan nilai-nilai etika Islami, memanfaatkan upayapembangunan sosial-ekonomi di wilayah tersebut, meningkatkan investasi ekonomi di tingkatmakro. (Narastri, 2020)

Menurut Salman dan Nawaz (2018), memang terdapat celah dan perbedaan yang luasantara sistem konvensional dan sistem syariah dalam berbagai bidang. Masyarakat cenderunglebih mempercayakan keuangan mereka pada lembaga keuangan dengan landasan syariah.Prinsip dasar dalam menjalankan transaksi keuangan adalah sesuai dengan al-quran dan al-hadis.Pada dasarnya akad yang terdapat pada fintech (muamalab) selama tidak 


\section{Vol 8, No 2: Agustus 2021. 66-77 \\ ISSN: 2460-9889 (Cetak) \\ ISSN: 2580-3565 (Online)}

https://journal.trunojoyo.ac.id/dinar/index

bertentangan denganprinsip syariah maka hal tersebut diperbolehkan (Al-ashlu fil muamalah al ibahah). Selain itufintech merujuk pada salah satu asas muamalah lainnya yaitu an-taradhin yang memilik artisaling ridho diantara keduanya. Perlu diperhatikan dengan cermat pula unsur-unsur syariah,sebagaimana yang disampaikan al-Ghazali dalam bifz ad-din, hifz-an-nafs, bifz al-aql, hifz-annasl,dan hifzal-mal. Dengan adanya fintech ini adalah sebagai upaya memudahkan setiap orangdalam bertransaksi dan investasi berdasarkan prinsip syariah.

Beberapa prinsip syariah ini mengatur bagaimana proses hingga sampai pada tujuan akhir,dapat dilakukan dengan baik dan benar.Saat ini kendala yang dihadapi oleh fintech berbasis syariah, yaitu terkait perbedaanakad yang digunakan. Beberapa jenis fintech yang telah diatur kesyariahannya adalah jenis Peerto Peer Lending (pinjaman berbasis teknologi), uang elektronik (e-Money), dan gerbangpembayaran (payment gateway). Hukum syariah yang mengatur financial technology belum memiliki kepastian hukumnya, beberapa jenis fintech seperti crowdfunding, market aggregator, risk Einvestment management belum memiliki fatwa syariahnya. Maka perlu adanya kepastian hukum syariah yang harus selaras dengan dinamika perkembangan teknologi. (Novi, 2020)

\section{Klasifikasi Financial Technology (Fintech)}

Ada berbagai ragam layanan dan produk yang bisa dimanfaatkan oleh masyarakat yang menggunakan Financial Technology. Bank Indonesia membagi klasifikasi fintech menjadi 4 (empat) jenis, yaitu: pertama Peer-to-Peer (P2P) Lending dan Crowdfunding, Fintech jenis P2P lending dan crowdfunding ini seperti marketplace finansial. Platform tersebut dapat mempertemukan dua pihak, yaitu pihak yang dapat memberikan dana dan pihak yang memerlukan dana sebagai modal maupun investasi. Peer-to-peer lending atau P2P lending juga dapat diartikan sebagai suatau layanan untuk meminjamkan dana kepada masyarakat, dana tersebut dapat berasal dari perusahan pembangun platform tersebut dan/atau berasal dari masyarakat itu sendiri.

Kedua, Manajemen Risiko Investasi. Fintech jenis ini bisa digunakan untuk dapat melakukan berbagai perencanaan keungan dan/atau dapat melakukan pemantauan kondisi keuangan sehingga menjadi lebih praktis dan mudah. Jenis fintech manajemen risiko investasi memang sangat praktis dan mudah digunakan, penguna hanya perlu memberikan data diri atau informasi yang dibutuhkan untuk bisa mengontorl keungan, dan fitur ini biasanya dapat diakes melalui smartphine pengguna.

Ketiga, Payment, Clearing, dan Settlement, Kategori fintech dengan jenis Payment, Clearing, dan Settlement adalah yang pertama startup finansial yang memberikan layanan berupa dompet digital atau payment gateway, yang kedua digital fintech ini memberikan layanan yang menghubungkan bisnis e-commerce dengan berbagai bank yang ada di Indonesia sehingga pembeli dan penjual dapat dengan mudah melakukan traksaksi.

Keempat, Market Aggregator. Fintech market aggregator memberikan berbagai macam informasi kepada penggunanya terkait dengan setor keuangan. Fintech jenis ii biasanya memiliki cakupan informasi yang banyak terkait dengan keuangan, kartu kredit, tips, dan investasi keuangan, dan lain lain. Dengan adanya fintech aggregator, maka pengguna diharapkan bisa menyerap banyak informasi keuangan sebelum pengguna mengambil keputusan (PRESTAMA, IQBAL, \& RIYADI, 2019). 


\section{Penelitian Terkait}

Perkembangan fintech di Indonesia saat ini sedang mengalami trend dan peningkatan yang positif sehingga banyak dipilih dan digunakan masyarakat untuk layanan transaksi keuangan digital. Menurut data dari Menko Perekonomian banyaknya fintech yang berkembang Peer-to-Peer (P2P) Lending yang mana merupakan jenis fintech yang peningkatannya cukup signifikan dibandingkan beberapa jenis fintech lainnya seperti payment, wealth management dan lainnya. Akan tetapi, peningkatan yang terlihat pada fintech di Indonesia juga tidak pernah terlepas dari tantangan dalam pengembangannya di industri finansial Indonesia. Tantangan yang dimaksud seperti penyalahgunaan data pribadi, pengguna layanan dan risiko pencucian uang.

Salah satu penelitian terkait yang pernah ada adalah "Dampak Pandemi Covid-19 Terhadap Pertumbuban Ekonomi Indonesia dan Solusinya" oleh D. Wuryandani yang dalam penelitiannya lebih banyak membahas tentang kajian dari dampak Covid-19 pada perekonomian indonesia dan solusinya. Salah satunya dengan mempercepat belanja pemerintah atau dengan menambah anggaran untuk bantuan sosial serta bantuan langsung tunai (BLT). DPR sebagai sebuah institusi yang bertugas dan memiliki fungsi pengawasan perlu mendesak pemerintah untuk membuat kebijakan tentang upaya-upaya dalam mendorong percepatan pemulihan ekonomi secara nasional. Selanjutnya penelitian yang dilakukan oleh Mulyana yang berjudul "Analisa Implementasi Pendanaan Syariah Dengan Akad Musyarakah Melalui Fintech Syariah (Studi Kasus Pendanaan Usaha Pertanian Horenzo Di PT Amanna Fintech Syariab)". yang dalam penelitiannya menjelaskan tentang peran fintech syariah dalam mendorong dan berkontribusi terhadap pertumbuhan UMKM sehingga secara langsung ikut berkontribusi dalam menumbuhkan perekonomian secara nasional.

\section{Metode Penelitian}

Penelitian ini merupakan jenis penelitian studi literature dengan pendekatan analisis Metode deskriptif kualitatif, yaitu prosedur penelitian yang dihasilkan berupa kata-kata tertulis maupun lisan dari orang-orang dan perilaku yang dapat diamati dan akan memberikan gambaran hasil penelitian.

Teknik pengumpulan data menggunakan pendekatan studi literatur. Dimana literatur yang digunakan melalui input data-data sekunder yang dikumpulkan melalui artikel ilmiah, artikel media massa baik elektronik maupun cetak (internet), buku teks, artikel media massa, hingga penelusuran literatur online yang berkaitan dengan penelitian ini. Kemudian data-data yang terkumpul diproses dan dianalisis sesuai dengan permasalahan yang diangkat dalam karya tulis dan output yaitu dengan penyajian data berupa karya tulis ilmiah.

Teknik analisis data, yaitu menganalisis data-data tentang fintech syariah yang dikumpulkan kemudian data tersebut dikelompokkan dan dianalisis sehingga mendapati kesimpulan tentang fintech syariah yang berkontribusi serta dinilai positif terhadap pemulihan ekonomi nasional dan peningkatan pemasukan negara dimasa pandemic.

\section{Hasil dan Pembahasan}

Berdasarkan data pada studi Asosiasi Fintech Indonesia dan INDEF, penyaluran dana fintech dan investasi telah menyumbang output nasional sedikitnya mencapai Rp 26 triliun. Kemudian pada tahun 2019 penyaluran dana dan investasi pada fintech mengalami kenaikan dengan menyumbang sebesar Rp 60 triliun atau meningkat sebesar 130\% 
dibandingkan dengan tahun sebelumnya. Terjadi lonjakan pada penyaluran dana yang sangat besar pada periode 2018-2019 yang hal ini dapat disimpulkan bahwa inovasi keuangan pada bidang fintech nyatanya memiliki dampak yang cukup signifikan terhadap perekonomian di Indonesia.

Dampak pertumbuhan ekonomi dengan adanya penyaluran dana oleh fintech dapat dilihat pada tabel berikut ini:

\section{Penyaluran fintech Lending Pada Sektor Ekonomi}

\section{Tabel 1}

Dampak Fintech terhadap Pertumbuhan Ekonomi

\begin{tabular}{|c|c|c|c|c|}
\hline \multirow[b]{2}{*}{ Produk } & \multicolumn{2}{|c|}{2019} & \multicolumn{2}{|c|}{2020} \\
\hline & $\begin{array}{l}\text { Penambahan nilai } \\
\text { (juta rupiah) }\end{array}$ & Perubahan $(\%)$ & $\begin{array}{l}\text { Penambahan nilai } \\
\text { (juta rupiah) }\end{array}$ & Perubahan $(\%)$ \\
\hline $\begin{array}{l}\text { Pertanian, } \\
\text { Kehutanan dan } \\
\text { Perikanan }\end{array}$ & $276,609.78$ & 0.023 & $49,152.89$ & 0.004 \\
\hline $\begin{array}{l}\text { Pertambangan dan } \\
\text { Penggalian }\end{array}$ & $288,885.21$ & 0.031 & $51,459.65$ & 0.005 \\
\hline Industri Pengolahan & $469,356.96$ & 0.011 & $79,333.83$ & 0.002 \\
\hline $\begin{array}{l}\text { Pengadaan listrik } \\
\text { dan gas }\end{array}$ & $786,101.99$ & 0.254 & $183,201.18$ & 0.059 \\
\hline $\begin{array}{l}\text { Pengadaan air, } \\
\text { Pengelolaan smpah } \\
\text { dan limbah serta } \\
\text { daur ulang }\end{array}$ & $720,309.86$ & 3.025 & $103,815.98$ & 0.436 \\
\hline Kontruksi & $138,914.00$ & 0.008 & $21,270.65$ & 0.001 \\
\hline $\begin{array}{l}\text { Perdagangan Mobil } \\
\text { dan Sepeda Motor } \\
\text { serta Reparasi }\end{array}$ & $417,559.79$ & 0.161 & $69,125.08$ & 0.027 \\
\hline $\begin{array}{l}\text { Perdagangan Selain } \\
\text { Mobil dan Sepeda } \\
\text { Motor }\end{array}$ & $7,220,918.52$ & 0.650 & $55,507.30$ & 0.005 \\
\hline $\begin{array}{l}\text { Trasportasi dan } \\
\text { Pergudangan }\end{array}$ & $648,940.97$ & 0.118 & $104,827.09$ & 0.019 \\
\hline $\begin{array}{l}\text { Penyediaan } \\
\text { Akomodasi dan } \\
\text { Makan Minum }\end{array}$ & $273,988.89$ & 0.062 & $67,283.83$ & 0.015 \\
\hline $\begin{array}{l}\text { Informasi dan } \\
\text { Komunikasi }\end{array}$ & $811,886.26$ & 0.198 & $492,964.58$ & 0.121 \\
\hline $\begin{array}{l}\text { Jasa Keuangan } \\
\text { Perbankan }\end{array}$ & $1,577,659.96$ & 0.820 & $1,949,987.80$ & 1.013 \\
\hline Jasa Asuransi & $1,924,451.90$ & 3.489 & $1,512,957.27$ & 2.743 \\
\hline Jasa Dana Pensiun & $905,046.74$ & 6.954 & $3,323,997.09$ & 25.539 \\
\hline $\begin{array}{l}\text { Jasa Lembaga } \\
\text { Keuangan Lainnya }\end{array}$ & $7,403,789.98$ & 10.217 & $49,347,376.41$ & 68.098 \\
\hline Jasa Real Estate & $576,192.78$ & 0.234 & $76,742.41$ & 0.031 \\
\hline Jasa Perusahaan & $1,210,475.40$ & 0.596 & $598,521.38$ & 0.295 \\
\hline $\begin{array}{l}\text { Jasa Pemerintahan } \\
\text { Umum }\end{array}$ & $54,120.70$ & 0.013 & $51,641.58$ & 0.012 \\
\hline Jasa Pendidikan & $42,466.00$ & 0.014 & $37,131.61$ & 0.012 \\
\hline $\begin{array}{l}\text { Jasa Kesehatan dan } \\
\text { Kegiatan Sosial }\end{array}$ & $97,572.55$ & 0.065 & $34,866.72$ & 0.023 \\
\hline Jasa Lainnya & $122,934.00$ & 0.102 & $1,866,650.34$ & 1.556 \\
\hline PDB & $25,968,182.27$ & 0.198 & $60,077,814.68$ & 0.458 \\
\hline
\end{tabular}

Sumber : INDEF (2020) 
Berdasarkan data di atas, bahwa yang memiliki dampak terbesar salah satunya adalah jasa keuangan perbankan, asuransi dan dana pensiun yang kemudian masing-masing tumbuh 1,01\%,2,7\% dan 25,3\%. Keberadaan fintech yang ditunjukkan oleh data di atas ternyata malah membuat sektor keuangan perbankan mengalami kenaikan, termasuk didalamnya yang berkaitan dengan kegiaytan kerjasama escrow account (penitipan dana) dan virtual account di perbankan pada umumnya, kemudian sistem pembayaran sampai credit channeling. Beberapa bank umum bahkan pada saat ini membentuk modal ventura, sebagai unit dalam melakukan investasi secara langsung pada perusahaan fintech. Dalam upaya optimalisasinya, kerjasama yang dilakukan antara fintech dengan lembaga keuangan bank secara otomatis memiliki dampak pada lembaga keuangan bank yang turut dalam meperoleh imbal hasil dari menjamurnya fintech.

Disisi lain, jasa-jasa perusahaan seperti IT service, design graphic, bussines solution, co-working space, legal dan HR juga ikut terdampak dan mengalami kenaikan hingga $0,29 \%$.

\section{Penyaluran fintech Pada Pendapatan Masyarakat}

Berdasarkan data pada studi INDEF dan Asosiasi Fintech Indonesia, adanya investasi yang masuk dalam bidang Fintech dan kegiatan penyaluran dana oleh fintech berdampak pada adanya kenaikan pendapatan faktor produksi. Pada tabel berikut ini, dapat dilihat adanya dampak penyaluran Fintech P2P lending terhadap pendapatan masyarakat:

\section{Tabel 2}

\section{Dampak fintech Lending pada Pendapatan Masyarakat}

\begin{tabular}{|c|c|c|c|c|}
\hline \multicolumn{2}{|l|}{ Faktor Produksi } & \multirow{2}{*}{$\begin{array}{c}\text { Penambahan } \\
\text { Pendapatan } \\
\text { (miliar } \\
\text { rupiah) }\end{array}$} & \multirow{2}{*}{$\begin{array}{c}\text { Pendapatan } \\
\text { Awal (miliar } \\
\text { rupiah) }\end{array}$} & \multirow{2}{*}{$\begin{array}{c}\begin{array}{c}\text { Prosentase } \\
\text { Perubahan } \\
(\mathbf{0})\end{array} \\
1.20\end{array}$} \\
\hline Pertanian penerima & Desa & & & \\
\hline upah dan gaji & Kota & 424.54 & $35,006.16$ & 1.21 \\
\hline \multirow{2}{*}{$\begin{array}{l}\text { Pertanian bukan } \\
\text { penerima upah dan } \\
\text { gaji }\end{array}$} & Desa & $4,788.34$ & $387,957.53$ & 1.23 \\
\hline & Kota & 509.26 & $40,419.47$ & 1.26 \\
\hline \multirow[b]{2}{*}{$\begin{array}{l}\text { Produksi, Operator } \\
\text { alat angkutan, } \\
\text { manual dan buruh } \\
\text { kasar pnerima upah } \\
\text { dan gaji }\end{array}$} & Desa & $1,371.02$ & $220,335.47$ & 0.62 \\
\hline & Kota & $3,320.53$ & $413,958.41$ & 0.80 \\
\hline \multirow{2}{*}{$\begin{array}{l}\text { Produksi, Operator } \\
\text { alat angkutan, } \\
\text { manual dan buruh } \\
\text { kasar bukan } \\
\text { penerima upah dan } \\
\text { gaji }\end{array}$} & Desa & $1,013.47$ & $132,047.46$ & 0.77 \\
\hline & Kota & $1,104.58$ & $120,263.77$ & 0.92 \\
\hline \multirow{2}{*}{$\begin{array}{l}\text { Tata usaha, } \\
\text { Penjualan, Jasa-jasa } \\
\text { penerima upah dan } \\
\text { gaji }\end{array}$} & Desa & $2,395.24$ & $92,286.64$ & 2.60 \\
\hline & Kota & $11,248.62$ & $435,131.74$ & 2.59 \\
\hline \multirow{2}{*}{$\begin{array}{l}\text { Tata usaha, } \\
\text { Penjualan, Jasa-jasa } \\
\text { bukan penerima } \\
\text { upah dan gaji }\end{array}$} & Desa & $1,553.64$ & $150,447.17$ & 1.03 \\
\hline & Kota & $2,421.78$ & $226,526.38$ & 1.07 \\
\hline
\end{tabular}




\begin{tabular}{|l|l|l|c|c|c|}
\hline & $\begin{array}{l}\text { Kepemimpinan, } \\
\text { Ketatalaksanaan, } \\
\text { Militer, Profesional, } \\
\text { dan Teknisi } \\
\text { penerima upah dan } \\
\text { gaji }\end{array}$ & Desa & $1,022.60$ & $70,180.93$ & 1.46 \\
\cline { 2 - 5 } & $\begin{array}{l}\text { Kepemimpinan, } \\
\text { Ketatalaksanaan, } \\
\text { Militer, Profesional, } \\
\text { dan Teknisi bukan } \\
\text { penerima upah dan } \\
\text { gaji }\end{array}$ & Desa & 138.672 .89 & $192,172.92$ & 2.06 \\
\cline { 2 - 5 } & Kota & 385.07 & $33,451.07$ & 1.07 \\
\hline Bukan Tenaga Kerja & & $43,680.41$ & $2,470,974.96$ & 1.15 \\
\hline Total Faktor Produksi & & & & 1.77 \\
\hline
\end{tabular}

Sumber : INDEF (2020)

Berdasarkan pada data tabel di atas terlihat bahwa ada kenaikan pendapatan pada faktor produksi sebesar 1,57\%. Terjadi kenaikan pada tenaga kerja tata usaha, penjualan dn jasa dengan pendapatan tertinggi baik didesa maupun di kota. Dengan rata-rata kenaikan pada masing-masing golongan mencapai $2 \%$. Penyaluran yang dilakukan oleh fintech pada sektor perdagangan pada saat ini telah banyak dilakukan dengan objek masyarakat pekerja yang pada umumnya telah mengenal tehnologi smartphne. Oleh karenanya keberadaaan fintech telah banyak dimanfaatkan pada sektor tenaga kerja, tata usaha, penjulan dan jasa baik di desa maupun di kota dengan kenaikan pendapatan yang signifikan.

Selain itu pada masyarakat pedesaan, pemanfaatan fintech dalam kegiatan peyaluran dana dan investasinya berdampak pada sektor pertanian dan usaha penunjang pertanian. Hal ini didasari bahwa, yang menjadi objek dari penyaluran dana fintech terfokus pada sektorsektor ekonomi yang dalam hal ini masih minim sentuhan dari institusi perbankan seperti pada sektor pertanian di daerah pedesaan.

\section{Penyaluran fintech Terhadap Institusi Ekonomi}

Dampak dari adanya penyaluran dana investasi fintech yang didasari oleh data ilmiah pada studi INDEF dan Asosiasi Fintech Indonesia yang mana telah mendorong naiknya pendapatan pada sektor instistusi ekonomi, dapat dilihat pada tabel berikut ini:

\section{Tabel 3}

Dampak fintech Terhadap Institusi Ekonomi

\begin{tabular}{|c|c|c|c|c|c|}
\hline \multicolumn{3}{|r|}{ Institusi Ekonomi } & $\begin{array}{l}\text { Penambahan } \\
\text { Pendapatan }\end{array}$ & $\begin{array}{l}\text { Pendapatan } \\
\text { Awal (miliar }\end{array}$ & $\begin{array}{l}\text { Persentase } \\
\text { Perubahan }\end{array}$ \\
\hline \multirow{4}{*}{ 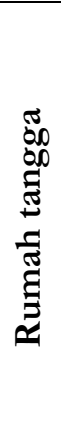 } & \multicolumn{2}{|c|}{ Buruh tani } & $2,287.22$ & $176,756.68$ & 1.29 \\
\hline & \multicolumn{2}{|c|}{ Pengusaha Pertanian } & $9,767.10$ & $731,562.84$ & 1.34 \\
\hline & \multirow[t]{2}{*}{ Pedesaan } & $\begin{array}{l}\text { Pelaku usaha bebas golongan } \\
\text { rendah, tenaga TU, pedagang } \\
\text { keliling, pekerja bebas sektor } \\
\text { angkutan, jasa perorangan, buruh } \\
\text { kasar }\end{array}$ & $5,676.12$ & $494,234.22$ & 1.15 \\
\hline & & $\begin{array}{l}\text { Bukan merupakan angkatan kerja } \\
\text { dan golongan tidak jelas }\end{array}$ & $2,073.81$ & $173,151.85$ & 1.20 \\
\hline
\end{tabular}




\begin{tabular}{|c|c|c|c|c|}
\hline & $\begin{array}{l}\text { Pelaku usaha bebas golongan atas, } \\
\text { pelaku usaha bukan pertanian, } \\
\text { manajer, militer, profesional, teknisi, } \\
\text { guru, para pekerja TU, dan } \\
\text { penjualan golongan atas. }\end{array}$ & $6,900.07$ & $468,454.50$ & 1.47 \\
\hline \multirow[t]{3}{*}{ Kota } & $\begin{array}{l}\text { Pelaku usaha bebas golongan } \\
\text { rendah, tenaga TU, pedagang } \\
\text { keliling, pekerja bebas sektor } \\
\text { angkutan, jasa perorangan, buruh } \\
\text { kasar }\end{array}$ & $9,552.56$ & $710,495.47$ & 1.34 \\
\hline & $\begin{array}{l}\text { Bukan merupakan angkatan kerja } \\
\text { dan golongan tidak jelas }\end{array}$ & $3,829.21$ & $243,905.48$ & 1.57 \\
\hline & $\begin{array}{l}\text { Pelaku usaha bebas golongan atas, } \\
\text { pelaku usaha bukan pertanian, } \\
\text { manajer, militer, profesional, teknisi, } \\
\text { guru, para pekerja TU, dan } \\
\text { penjualan golongan atas. }\end{array}$ & $14,642.66$ & $827,883.49$ & 1.77 \\
\hline \multicolumn{2}{|l|}{ Perusahaan } & $32,659.42$ & $1,916,701.71$ & 1.70 \\
\hline \multicolumn{2}{|l|}{ Pemerintah } & $14,369.37$ & $1,264,033.42$ & 1.14 \\
\hline \multicolumn{2}{|l|}{ Total } & $101,757.56$ & $7,007,179.66$ & 1.45 \\
\hline
\end{tabular}

Sumber : INDEF (2020)

Terlihat pada tabel diatas, adanya penyaluran dana investasi yang dilakukan oleh fintech berdampak pada kenaikan pendapatan pada seluruh sektor institusi ekonomi yaitu pada rumah tangga, perusahaan maupun pemerintah. Kenaikan pendapatan pada seluruh sektor institusi ekonomi tercatat sebesar 1,45\% atau adanya tambahan kenaikan 101,7 milyar. Prosentase kenaikan tertinggi yaitu dari sektor rumah tangga perkotaan dimana termasuk didalamnya para pelaku usaha golongan atas dengan kenaikan sebesar 1,77\%, sedangkan prosentase pada sektor rumah tangga perkotaan untuk pelaku usaha golongan bawah tercatat kenaikan sebesar 1,34\%, sama halnya dengan sektor rumah tangga pada usaha pertanian dengan kenaikan sebesar 1,34\%. Dampak kenaikan yang terjadi dengan adanya penyaluran dana investasi oleh fintech nayatanya masih didominasi oleh sektor rumah tangga perkotaan diberbagai kalangan serta rumah tangga pada usaha pertanian dibanding pada sektor rumah tangga pedesaan.

Hasil prosentase pendapatan pada perusahaan, tercatat adanya kenaikan sebesar $1,7 \%$ atau 32,6 milyar dengan adanya penyaluran dana investasi oleh fintech. Sedangkan pada sektor pemerintahan, terjadi kenaikan $1,14 \%$ atau sebesar 14,3 milyar rupiah yang didapatkan dari adanya penyaluran dana investasi yang dilakukan oleh fintech.

\section{Kesimpulan}

Dari hasil pembahasan, maka dapat disimpulkan bahwa keberadaan akan Financial Technology (fintech) memiliki dampak positif ditengah pandemi covid-19. Kontribusi yang diberikan ini tergambar dengan adanya masyarakat yang telah banyak terbantu dan terlayani oleh lembaga keuangan formal dalam aktivitas transaksi keuangannya sesuai dengan kebutuhan masyarakat. Dalam rangka pemulihan ekonomi secara nasional dan peningkatan pada penerimaan negara dimasa pandemic covid-19 dapat ditingkatkan dengan adanya 


\section{Vol 8, No 2: Agustus 2021. 66-77 \\ ISSN: 2460-9889 (Cetak) \\ ISSN: 2580-3565 (Online)}

https://journal.trunojoyo.ac.id/dinar/index

dukungan penguatan regulasi yang ada terhadap pertumbuhan fintech yang inklusif, massif dan berkelanjutan yang nantinya akan berpotensi sebagai faktor pemicu akan lompatan bagi industri pembayaran layanan keuangan digital yang sangat besar.

Untuk mengoptimalkan peran fintech syariah dalam rangka pemulihan ekonomi secara nasional perlu adanya dukungan dan keterlibatan dari semua pihak yang terkait didalamnya, termasuk juga adanya peningkatkan pelayanan keuangan kepada masyarakat secara luas. Penyaluran pembiayaan yang dilakukan melalui fintech syariah bisa juga dilengkapi dengan pemberlakukan proses pendampingan dan pelatihan pada program pengenalan literasi keuangan islam berbasis digital. Pelatihan dan pemahaman tentang literasi keuangan dalam islam yang diselenggarakan akan membantu program pemerintah terkhusus Otoritas Jasa Keuangan (OJK) dalam meningkatkan pengetahuan masyarakat yang terkait pada sektor financial yang mana sebagai bagian dari upaya dalam peningkatan kesejahteraan masyarakat.

\section{Daftar Pustaka}

Alwi, A. B. (2018). Pembiayaan Berbasis Teknologi Informasi (Fintech) yang Berdasarkan Syariah. Al-Qanun: Jurnal Pemikiran Dan Pembaharuan Hukum Islam, 21(2), 255-271. https://doi.org/10.15642/alqanun.2018.21.2.255-271

Hasan, R., Hassan, M. K., \& Aliyu, S. (2020). Fintech and Islamic Finance: Literature

Review and Research Agenda. International Journal of Islamic Economics and Finance (IJIEF), 3(1). https:// doi.org/10.18196/ijief.2122

Marginingsih, R. (2021). Financial Technology (Fintech) Dalam Inklusi Keuangan

Nasional di Masa Pandemi Covid-19. Moneter - Jurnal Akuntansi Dan Keuangan, 8(1), 56-64. https://doi.org/10.31294/moneter.v8i1.9903

Miskam, S., Yaacob, A. M., \& Rosman, R. (2019). Fintech and Its Impact on Islamic Fund Management in Malaysia: A Legal Viewpoint. In Emerging Issues in Islamic Finance Law and Practice in Malaysia (pp. 223-246). https:/ / doi.org/10.1108/978-1-78973-545120191019

Narastri, M. (2020). Financial Technology (Fintech) Di Indonesia Ditinjau Dari Perspektif Islam. Indonesian Interdisciplinary Journal of Sharia Economics (IIJSE), 2(2), 155-170. https://doi.org/10.31538/iijse.v2i2.513

Novi, M. (n.d.). Konsep Fintech Lending Dalam Perspektif Maqā ș id Syarī' ah. 6(1), 101-122.

Bank Indonesia. (2020). Booklet Keuangan Inklusif. Retrieved December 28, 2020, from https://www.bi.go.id/id/fungsiutama/stabilitas-sistem-

keuangan/keuanganinklusif/Default.aspx INDEF. (2019).

Studi Dampak Fintech P2P Lending terhadap Perekonomian Nasional. Retrieved January 5, 2021, from https://indef.or.id/source/research/Studi Dampak Fintech P2P Lending terhadap Perekonomian Nasional.pdf $\% 0 \mathrm{~A} \% 0 \mathrm{~A}$

Katadata. (2020). Januari 2020, Akumulasi Penyaluran Pinjaman Fintech Lending Naik 240\%. Retrieved December 27, 2020, from https://databoks.katadata.co.id/datapublish/202 0/03/12/januari-2020-akumulasipenyaluranpinjaman-fintech-lending-naik-240\# Keuangan, O. J. (2020).

Statistik Fintech Indonesia. Retrieved December 28, 2020, from https://www.ojk.go.id/id/kanal/iknb/data-danstatistik/fintech/Default.asp

PRESTAMA, F. B., IQBAL, M., \& RIYADI, S. (2019). POTENSI FINANSIAL 
TEKNOLOGI SYARIAH DALAM MENJANGKAU PEMBIAYAAN NON-

BANK. Al-Masraf: Jurnal Lembaga Keuangan Dan Perbankan, 4(2), 147.

https://doi.org/10.15548/al-masraf.v4i2.264

Peraturan Bank Indonesia tentang Penyelenggaraan Teknologi Finansial. (PBI No.19/12/PBI/2017)

Peraturan Otoritas Jasa Keuangan. Nomor 76 /Pojk.07/2016. Tentang. Peningkatan Literasi dan Inklusi Keuangan di Sektor Jasa.

Keuangan, O. J. (2020). Statistik Fintech Indonesia. Retrieved December 28, 2020, from https://www.ojk.go.id/id/kanal/iknb/data-danstatistik/fintech/Default.a

Trimulato, T. (2019). Fintech for Sharia Micro Finance Institution: Qualitative Analysis toward Utilization of Financial Technology in BPRS and BMT. AL-F ALAH: Journal of Islamic Economics, 4(2), 123. https://doi.org/10.29240/alfalah.v4i2.917

Wuryandani, D. (2020). Dampak Pandemi Covid-19 terhadap Pertumbuhan ekonomi Indonesia 2020 dan Solusinya. Pusat Penelitian Badan Keablian DPR RI, Bidang Ekonomi Dan Kebijakan Publik.

Yarli, D. (2018). Analisis Akad Tijarah Pada Transaksi Fintech Syariah Dengan Pendekatan Maqhasid. YUDISIA : Jurnal Pemikiran Hukum Dan Hukum Islam, 9(2). https://doi.org/10.21043/yudisia.v9i2.4766 